\title{
Análise de componentes principais do desempenho zootécnico e qualidade dos ovos de poedeiras
}

\author{
Natália Thaís Goncalves Koivama Lúcio Francelino Araújo \\ Universidade de São Paulo - FZEA, USP \\ 13.635-900, Pirassununga, SP \\ E-mail:nataliakoiyama@usp.br, lfaraujo@usp.br \\ Bruno Rogério Locatelli dos Santos João Vitor Teodoro \\ Universidade Federal da Grande Dourados - FACET, UFGD \\ 79.804-970, Dourados, MS \\ E-mail: brunolocatelli@ufgd.edu.br, joaoteodoro@ufgd.edu.br
}

\section{RESUMO}

As leveduras são reconhecidas por conferirem atuações especializadas que beneficiam o desempenho zootécnico e os produtos oriundos dos animais suplementados, além de atuarem como imunoestimulantes [4]. Foram realizados dois experimentos, o experimento I com $0,1,2$ e $4 \mathrm{~kg} /$ ton da inclusão de levedura hidrolisada (Hilyses ${ }^{\circledR}$, ICC Brazil), e o experimento II com 0, 225, 450 e $900 \mathrm{~g} /$ ton de parede celular de levedura (Immunowall ${ }^{\circledR}$, ICC Brazil) na dieta de poedeiras de 37 a 40 semanas de idade. Foram avaliados os dados de desempenho zootécnico (consumo de ração, produção de ovos, conversão alimentar por kg/dúzia (CA/Dúzia) e kg/massa (CA/Massa) de ovos) e de qualidade dos ovos (peso do ovo, resistência à quebra, espessura da casca, coloração da gema (YCF), altura de albúmen (HT) e unidade Haugh (UH)).

As variáveis foram submetidas ao seguinte modelo, que inclui efeitos de análise e tratamento e fornece os valores residuais, $Y_{i j k}=A_{i}+T_{i j}+\varepsilon_{i j k}$, em que $Y_{i j k}$ são os valores observados para com a variável; $A_{i}$ é o efeito da análise $i, i=1,2 ; T_{i j}$ é o tratamento $j$ na análise $i ; \varepsilon_{i j k}$ é o resíduo. Este é um tipo de modelo hierárquico para cálculo dos resíduos a serem utilizados nas análises de correlação. Os resíduos $\left(\varepsilon_{i j k}\right)$ foram padronizados de forma a apresentar médias 0 e desvios padrão 1 .

Foram empregados os métodos multivariados para análises de componentes principais utilizando o pacote estatístico SAS [3]. Análise de componentes principais é um dos métodos multivariados mais simples, seu objetivo é tomar p variáveis e encontrar uma combinação linear para produzir índices que sejam não correlacionados na ordem de sua importância, e que descreva a variação nos dados [1].

Figura 1 - Variáveis ordenadas e coloridas por correlação

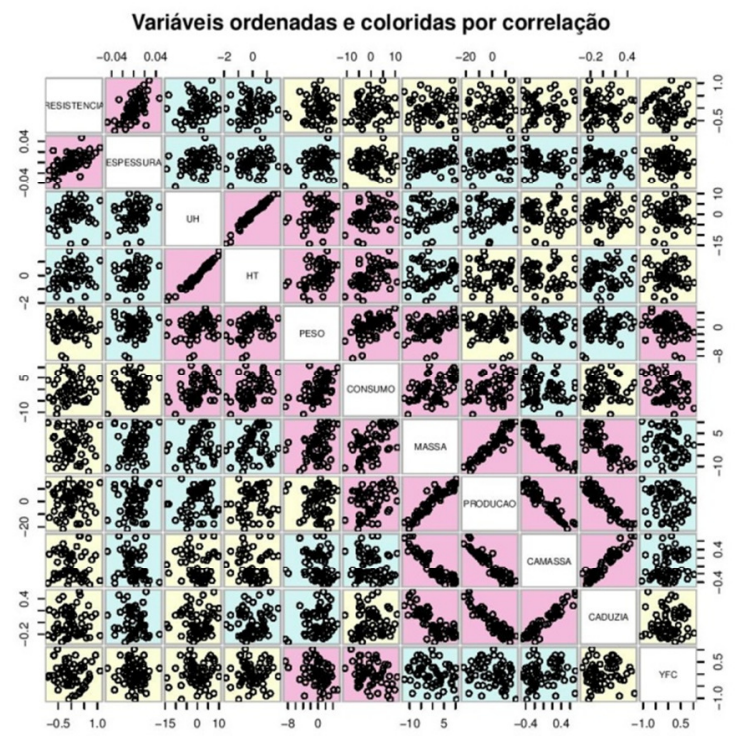

As variáveis que possuem uma alta correlação estão em rosa, as de média correlação em azul e de baixa correlação apresentadas em amarelo (Figura 1). Verifica-se uma alta correlação positiva entre a espessura e resistência da casca, já esperada, uma vez que quanto maior a espessura da casca do ovo maior sua resistência. $\mathrm{O}$ consumo de ração apresentou uma alta correlação positiva com o peso do ovo, um alto consumo de ração resulta em uma maior ingestão de proteína, levando a um suprimento das exigências de produção de ovos mais pesados [2]. No entanto, nem todos os pontos de ambas as correlações se 
encontraram ajustadas para uma aproximação linear, o que pode ser explicado por fatores externos como a temperatura ambiente que afeta a qualidade da casca e também o consumo de ração das aves. Há uma alta correlação positiva entre a altura do albúmen e unidade Haugh, estas variáveis estão relacionadas, pois a unidade Haugh é a altura do albúmen corrigida para o peso do ovo.

Entre as variáveis Massa e Produção, Produção e CA/Massa, foram encontradas altas correlações positivas e entre as variáveis Massa e CA/Massa, Massa e CA/Dúzia, Produção e CA/Dúzia, foram obtidas altas correlações negativas, possivelmente por estarem relacionadas com a variável funcional produção total de ovos. Com as variáveis CA/Massa e CA/Dúzia, foi verificada alta correlação positiva, possivelmente por estarem relacionadas com as variáveis funcionais produção total de ovos e consumo de ração.

$\mathrm{Na}$ análise de componentes principais verificou-se que um primeiro componente (PCR1) explica 37,24\%, um segundo componente (PCR2) 23,94\%, um terceiro componente (PCR3) $13,71 \%$ e um quarto componente (PCR4) $10,79 \%$ da variação dos dados. Assim os quatro componentes juntos explicam $85,69 \%$ da variabilidade dos dados.

Tabela 1 - Coeficientes de correlação entre as variáveis originais e os quatro primeiros componentes principais

\begin{tabular}{ccccc}
\hline \multirow{2}{*}{ Variável } & $\begin{array}{c}\text { Correlação com } \\
\text { PCR1 }\end{array}$ & $\begin{array}{c}\text { Correlação com } \\
\text { PCR2 }\end{array}$ & $\begin{array}{c}\text { Correlação com } \\
\text { PCR3 }\end{array}$ & $\begin{array}{c}\text { Correlação com } \\
\text { PCR4 }\end{array}$ \\
\hline ESPESSURA & 0.3908 & 0.2960 & $\mathbf{0 . 6 5 2 6}$ & -0.3630 \\
RESISTENCIA & 0.1909 & 0.3672 & $\mathbf{0 . 6 6 8 7}$ & -0.4551 \\
UH & 0.3322 & $\mathbf{0 . 7 8 1 8}$ & 0.1370 & 0.4400 \\
YFC & -0.2999 & -0.1206 & 0.4400 & $\mathbf{0 . 6 0 7 7}$ \\
HT & 0.3261 & $\mathbf{0 . 8 3 1 2}$ & 0.0571 & 0.4057 \\
PESO & 0.3540 & 0.5256 & -0.4278 & -0.2568 \\
CA/MASSA & $\mathbf{- 0 . 9 0 2 0}$ & 0.3770 & -0.0325 & -0.0673 \\
CA/DUZIA & $\mathbf{0 . 7 8 8 7}$ & 0.5541 & -0.1803 & -0.1546 \\
MASSA & $\mathbf{0 . 9 7 4 7}$ & -0.1131 & -0.1374 & 0.0062 \\
PRODUCAO & $\mathbf{0 . 9 2 8 2}$ & -0.3158 & 0.0041 & 0.0962 \\
CONSUMO & $\mathbf{0 . 4 7 7 1}$ & 0.5065 & -0.4294 & -0.1173 \\
\hline
\end{tabular}

O primeiro componente principal PCR1 (Tabela 1) está altamente associado às variáveis CA/Massa, CA/Dúzia, Massa, Produção e Consumo que representam o desempenho zootécnico das poedeiras, nomeando-se assim PCR1. O componente principal PCR2 está altamente associado às variáveis UH e HT, logo PCR2 pode ser nomeado como qualidade interna dos ovos. O componente principal PCR3 está altamente associado às variáveis Espessura e Resistência, podendo ser nomeado como qualidade externa dos ovos. Já para o componente principal PCR4 que está altamente associado à variável YFC, nomeia-se como coloração da gema. Este modelo pode ser aplicado na indústria de produção de ovos, uma vez que existe a busca constante por aumentar a eficiência produtiva e a qualidade dos ovos por meio do uso de aditivos na alimentação das aves.

Palavras-chave: Análise multivariada, espessura da casca, peso do ovo.

\section{Referências}

[1] B.F.J. Manly, "Métodos Estatístico Multivariados: uma introdução"; tradução Sara Ianda Carmona 3.ed.- Bookman, Porto Alegre, 2008

[2] R. Pinto, et al. Níveis de Proteína e Energia para Codornas Japonesas em Postura. R. Bras. Zootec. [online]., vol.31, n.4, pp. 1761-1770, (2002).

[3] Statistical Analysis System. SAS/STAT user'guide, version 8.0 ed. Cary: 1999. v.1, 943p.

[4] S. Yalçin, et al. Effects of dietary yeast autolysate (Saccharomyces cerevisiae) and black cumin seed (Nigella sativa L.) on performance, egg traits, some blood characteristics and antibody production of laying hens. Livest. Sci., vol.145, pp.13-20, (2012). 